\title{
Cross-border Cooperation and the Impact of Cross-border Financing Programs on the Local Development at the Eastern Borders of Romania
}

\author{
Adrian Buta \\ adrianbutagl@gmail.com \\ Mihaela Neculita \\ NeculitaM@yahoo.fr \\ Raluca Vasile Rusu \\ ralucarav@yahoo.com \\ Dunarea de Jos University of Galati, Romania
}

\begin{abstract}
With a view to elaborating local development initiatives and putting into effect certain local strategies, the community will always need structures that would call on crossborder cooperation programs in order to implement strategic projects in areas such as health, culture, entrepreneurship and education. This paper shows the opportunities provided by cross-border cooperation programs for local development using clear examples of implemented projects. The impact of implementing such initiatives is reflected in building external relations necessary for regions development, certain poles of regional development among European regions and regions outside the European Union. The paper proposes an integrate analysis of cross-border cooperation by means of data provided by national institutions. The purpose of the paper is to evaluate the impact of cross-border funding programs on local development and to find the reasons of present evolution.
\end{abstract}

Key words: regional development, cross-border cooperation, sustainability

JEL CODE: F02, F15, P18

\section{Introduction}

Cross-border cooperation is pursuing an efficient and sustainable relationship among the main actors involved in working out pragmatically certain common problems identified in the communities of the states in the area. Also, this can be used as a tool to reach purposes intended for enhancing the life quality and to develop strategic partnerships at cross-border level. For Galati County, the geographic position is a strong point that represents virtually the gateway to the European Union. (Prisecaru, 2004)

Throughout the implementation of cross-border cooperation programs, there have been identified some areas of interest for the development of partnership relations among communities in the border areas, focusing on health, culture, education, tourism and entrepreneurship. Certainly, the important factors in favoring these cooperation relations are cultural heritage, ethno-linguistic heritage and the historical one. The Romanian Community in Ukraine or the Ukrainian Community in Romania, then the common ethno-linguistic heritage of the populations of Romania and the Republic of Moldova, are important factors for the creation of efficient bilateral relations in the case of cross-border cooperation.

\section{Literature Review}

Cross-border cooperation proves to be "a type of classical mutual cooperation between two adjacent border regions". States, regions, administrative units take part in this at various social levels and/or groups, etc., including all fields of daily life and participating in the 
development of programs, priorities and common actions (Ibidem). With the development of the concept of European integration of the states in the Community structures, it comes to the fore a change in the way of viewing on the national states' borders. The latter benefit from an acceptance process on the background of integration into the European Union space. This step of extending the European Union towards the Eastern countries, materialized through the integration of several former communist states, led to a change of vision on the old community borders. (Iliec 2004)

The need for cross-border cooperation is especially targeted at the EU's external borders in order to maintain dialogue between both local public administrations and community citizens in the private area (companies, NGOs, etc.).

The balance created among the structures involved at cross-border level is a proof of the efficiency of cross-border cooperation which depends on the coordination of those involved in the development of medium- and long-term relations.

As a matter of fact, the texts of the European treaties stipulate for the need to ensure a balanced development, while curtailing the development inequality among the various European regions or countries. (Cross-border cooperation between Romania and Ukraine, respectively between Romania and the Republic of Moldova, Opportunities and challenges during 2014-2020)

Consequently, cross-border cooperation (Herman, 2011) is no longer a strict appanage of the states as international actors. An important part in this process is played by the local and regional administrative structures in the border areas, development associations built by them, but also the transnational corporations interested in promoting an economic and political environment favourable to business development and employment. (Catalin-Silviu Sararu, 2011). The EU interest is not only to harmoniously develop the regions on either side of the border or the security interest as concerns the development of a neighbouring cooperative and stable region, but also to re-enforce the European spirit and identity among its citizens, beyond their national and ethnic identities (Mircea Brie, Daniela Blaga, 2015).

The main objectives of the cross-border cooperation policy, as they are shown in the Romanian legislation, are the following:

„a) forwarding cooperation among regions, communities and authorities located on both sides of the border, for answering common problems, through the design and implementation of certain cross-border strategies and projects that would contribute to the development of those communities as regards the growth of living standard and economic development;

b) promoting neighbourliness, social stability and economic progress in the border regions, by financing projects with visible benefits for the regions and communities in these regions;

c) supporting the achievement of responsibility decentralization, by promoting local initiatives carried out within the local strategies "(Law 315 of 28 June 2004 (*updated*) concerning regional development in Romania, Chapter 1, Article 31,). (Webliography) 


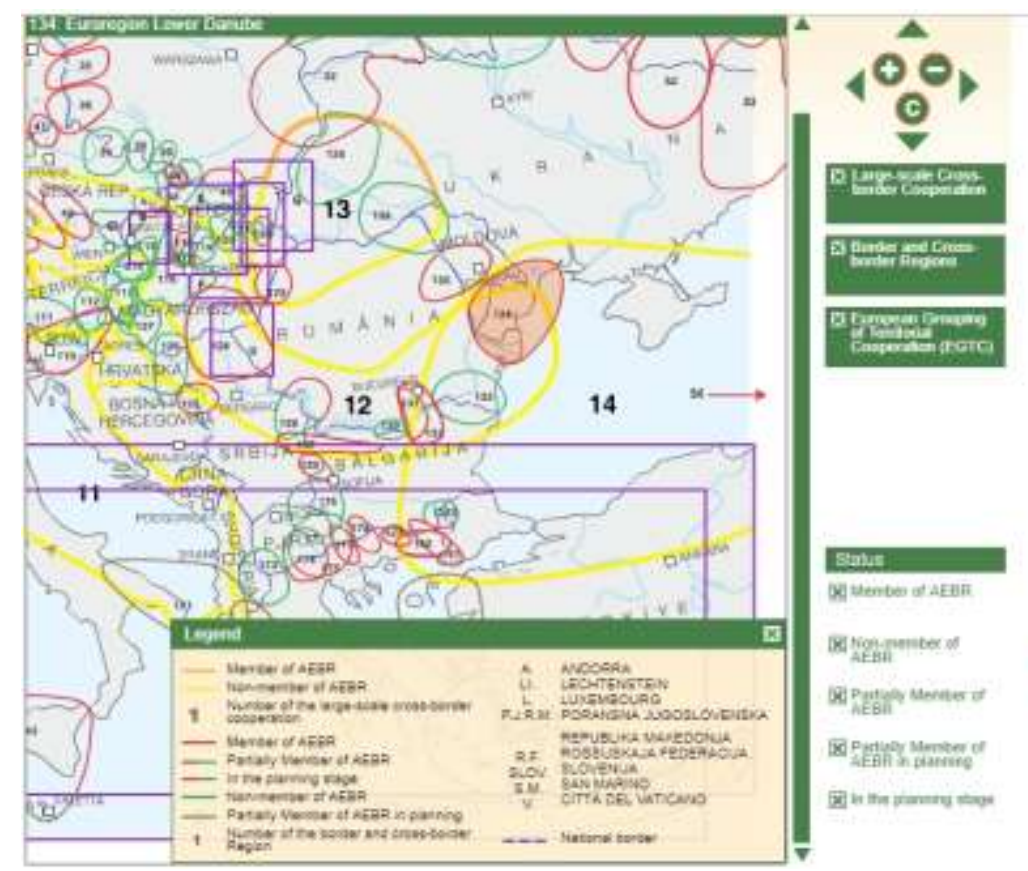

Map of cross-border cooperation at the Romanian borders https://www.aebr.eu/en/members/map of members.php

\section{Cross-border Cooperation at the Eastern Border of Romania with the Republic of Moldova and Ukraine}

As a member state of the European Union, Romania has access to the Structural Instruments allocated to the Objective of European Territorial Cooperation through the Territorial Cooperation Programs of the European Union, funded through the European Regional Development Fund, the Instrument for Pre-Accession Assistance and the European Neighborhood and Partnership Instrument. (Webliography)

The mission of Romania as an EU member state is not only to develop bilateral relations with its neighbors, but also to apply the EU neighborhood policy towards the Republic of Moldova and Ukraine. On analyzing legislation at national level, the cross-border cooperation is regulated by taking into account the formal framework of the European regulations. The various types of intergovernmental agreements, including conventions, protocols and treaties, continue to be part of the basic instruments necessary for enabling cross-border cooperation. For example, Romania and the Republic of Moldova, during 1991-2015, signed not less than 126 specific bilateral conventions and agreements. The cross-border cooperation relations in Romania and Ukraine are established on the basis of the Treaty of Good Neighborhood and Cooperation between the two states, signed in Constanta on 2 June 1997 and ratified by Romania through Law 129/1997 (Cătălin-Silviu Săraru, op. cit., p. 89 2011). Based on this agreement, the two countries signed subsequently several bilateral agreements with an impact on the cross-border cooperation field.

The regional authorities at the borders of Romania with Ukraine and the Republic of Moldova, the development associations have a significant role in outlining and developing crossborder cooperation. On the strength of the Romanian legislation, the regional and local public authorities in the border areas "may conclude with each other cross-border cooperation agreements with similar structures from the neighboring states", leading to the creation of "bodies having, according to national law, legal personality", but without having administrative 
powers (see Law No. 215 of 23 April 2001 (** republished **) (* updated *) of the local government (updated until 3 July $2008 *$ ), Article 15, (1), (3).

The financing programs with cross-border impact have propelled the foundation of regional or local organizations including associations of Euroregions type related to the border areas of Romania with the Republic of Moldova and Ukraine. In this manner, during the years of cooperation, the following organizations were set up for the purpose of facilitating cooperation and building new partnerships between public administrations and joint-purpose organizations from the three partner countries:

- The Carpathian Euroregion, this being officially set up in the Hungarian city of Debrecen, on the $14^{\text {th }}$ of February, 1993, on the occasion of the meeting of foreign ministers and local administrations representatives in Poland, Ukraine and Hungary. The Romanian State is part of this Euroregion since 29 April, 1997, through the counties of Bihor, Botoșani, Maramureș, Satu Mare, Sălaj, Suceava and Harghita.

- "Siret-Prut-Nistru" Euroregion appeared following a joint initiative of some county councils in Romania and the Republic of Moldova. The protocol for setting up this Euroregion was signed in Iasi on 18 September, 2002, but it gained legal personality only in 2005. The Euroregion currently includes the counties of Iași, Bistrița-Năsăud, Vaslui and Prahova in Romania and respectively most of the administrative territorial units that form the Republic of Moldova except for Transnistria200 (Găgăuzia was accepted as a member with full rights starting from January 1, 2015). (Webliography)

- The Lower Danube Euroregion is a step of regional association of local and regional authorities from the joint border of Romania, the Republic of Moldova and Ukraine. On 14 August, 1998, the three participating parties signed, in Galați, the agreement for the Euroregion foundation. The composition of the Lower Danube Euroregion is the following: from Romania, Galați, Brăila and Tulcea Counties, and from the Republic of Moldova, Cahul County and Cantemir County, and, from Ukraine, Odessa region. On the chance of a more efficient performance, especially in the field of attracting European funding, the Euroregion decided to turn into an association, thus, in March 2009 in Galati, the Association for Cross-border Cooperation "Lower Danube Euroregion" has been created. (Webliography)

At cross-border level, the Galați County benefits from two financing programs with cross-border impact in the relation with the Republic of Moldova and Ukraine: Joint Operational Program Romania- Republic of Moldova 2014-2020 and Joint Operational Program RomaniaUkraine 2014-2020.

The Joint Operational Program Romania-Republic of Moldova addresses to the area located at the border between Romania and the Republic of Moldova and will contribute to reaching the overall objective of the European Neighborhood Instrument: the evolution towards a region of prosperity and neighborliness, achieved through actions of cross-border cooperation for the benefit of the neighboring states which are or not EU members. The eligible area for financing is covered by: Romania - the counties: Botoșani, Iași, Vaslui, Galați; the Republic of Moldova, the entire country. 


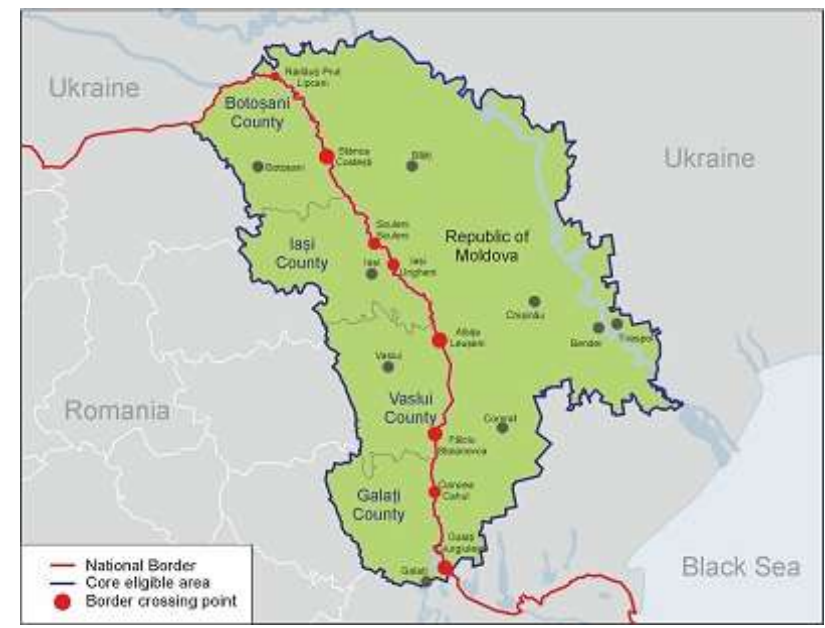

http://www.mdrap.ro/dezvoltare-regionala/-4970/-7572/-9278

\section{Budget of the Program:}

\section{Program Objectives}

EUR 89.1 million (89.1 million total budget - out of which 81 million are funded by the EU through the European Neighbourhood Instrument ENI and 8.1 million are cofinancing provided by the partner countries)

Flexibility rule: $10 \%$ of the Program budget can be used as follows:

-By the beneficiaries from Romania involved in Major Infrastructure Projects (MIPs) located outside the program area, on condition that their participation in the project is necessary for the project implementation and the eligibility criteria defined for each selection procedure are observed

-By beneficiaries, including project leaders, located in the program area, or by the Beneficiaries of Major Infrastructure Projects (MIPs) for the implementation of certain activities necessary to accomplish the project goals outside the program area.
Thematic objective 2: Support for education, research, technological development and innovation -

The

Thematic objective 3: Furthering local culture and historical heritage protection

Thematic objective 7: Improving accessibility in the regions, developing the transport and the common networks and systems of transport

Thematic objective 8: Common challenges in the field of safety and security

\section{Program Priorities}

Priority 1.1 - Institutional cooperation in the field of education with a view to improving the access to education and its quality Priority 1.2 - Promotion and support for research and innovation

Priority 2.1 - Promoting and preserving cultural and historical heritage

Priority 3.1 - Development of the cross-border transport infrastructure and the TIC infrastructure

Priority 4.1 - Support for the development of health services and access to health

Priority 4.2 - Support for joint activities in order to prevent natural and anthropic disasters, as well as joint actions during emergency situations 
In 2014-2020, the European Union will also finance the Joint Operational Program Romania-Ukraine through the European Neighbourhood Instrument (ENI). The program addresses to the border area between Romania and Ukraine and will contribute to the achievement of the overall objective of the European Neighbourhood Instrument: the evolution towards a region of prosperity and neighbourliness, made through cross-border cooperation actions, for the benefit of bordering states which are or not EU members. The eligible area for funding is covered by: Romania - the counties: Botoşani, Suceava, Tulcea, Maramureş, Satu-Mare; Ukraine - the oblasts: Odessa, Ivano-Frankivsk, Zakarpatska, Cernăuți.

\begin{tabular}{|c|c|c|}
\hline Budget of the Program: & Program Objectives & Program Priorities \\
\hline \multirow{2}{*}{$\begin{array}{l}\text { Euro } 66 \text { million }(66 \text { million total } \\
\text { budget - out of which } 81 \text { million } \\
\text { are funded by the EU through } \\
\text { the European Neighbourhood } \\
\text { Instrument - ENI and } 6 \text { million } \\
\text { are co-financing provided by the } \\
\text { partner countries) }\end{array}$} & \multirow[t]{2}{*}{$\begin{array}{l}\text { Thematic objective 2: Support } \\
\text { for education, research, } \\
\text { technological development and } \\
\text { innovation }\end{array}$} & $\begin{array}{l}\text { Priority } 1.1-\text { Institutional } \\
\text { cooperation in the field of } \\
\text { education with a view to } \\
\text { improving the access to } \\
\text { education and its quality }\end{array}$ \\
\hline & & $\begin{array}{l}\text { Priority } 1.2-\text { Promotion and } \\
\text { support for research and } \\
\text { innovation }\end{array}$ \\
\hline $\begin{array}{l}\text { Flexibility rule: } 10 \% \text { of the } \\
\text { Program budget can be used as } \\
\text { follows: }\end{array}$ & $\begin{array}{l}\text { Thematic objective 3: Furthering } \\
\text { local culture and historical } \\
\text { heritage protection }\end{array}$ & $\begin{array}{l}\text { Priority } 2.1-\text { Promoting and } \\
\text { preserving cultural and historical } \\
\text { heritage }\end{array}$ \\
\hline $\begin{array}{l}\text {-By the beneficiaries from } \\
\text { Romania involved in Major } \\
\text { Infrastructure Projects (MIPs) } \\
\text { located outside the program area, }\end{array}$ & $\begin{array}{l}\text { Thematic objective } 7 \text { : Improving } \\
\text { accessibility in the regions, } \\
\text { developing the transport and the } \\
\text { common networks and systems } \\
\text { of transport }\end{array}$ & $\begin{array}{l}\text { Priority } 3.1-\text { Development of } \\
\text { the cross-border transport } \\
\text { infrastructure and the TIC } \\
\text { infrastructure }\end{array}$ \\
\hline participation in the project is & $\begin{array}{l}\text { Thematic objective } 8: \text { Common } \\
\text { challenges in the field of safety } \\
\text { and security }\end{array}$ & $\begin{array}{l}\text { Priority } 4.1 \text { - Support for the } \\
\text { development of health services } \\
\text { and access to health }\end{array}$ \\
\hline $\begin{array}{l}\text {-By beneficiaries, including } \\
\text { procedure are observed } \\
\text { project leaders, located in the } \\
\text { program area, or by the } \\
\text { Beneficiaries of Major } \\
\text { Infrastructure Projects (MIPs) for } \\
\text { the implementation of certain } \\
\text { activities necessary to accomplish } \\
\text { the project goals outside the } \\
\text { program area. }\end{array}$ & & $\begin{array}{l}\text { Priority } 4.2-\text { Support for joint } \\
\text { activities in order to prevent } \\
\text { natural and anthropic disasters, as } \\
\text { well as joint actions during } \\
\text { emergency situations }\end{array}$ \\
\hline & & $\begin{array}{l}\text { Priority } 4.3-\text { Preventing and } \\
\text { fighting organized crime and } \\
\text { police cooperation }\end{array}$ \\
\hline
\end{tabular}

Sursa: http://www.fonduri-ue.ro/ro-ua 


\section{Projects of Cross-border Cooperation in Galați County}

The culture of program and project implementation is an essential dimension for stregthening cross-border cooperation. The efficiency, effectiveness, relevance and adequacy of interventions are criteria that indicate the level of project implementation culture in a given community or area of intervention. (Webliography)

For Galați County, the culture of implementing cross-border cooperation projects is maintained through the structures created at Euroregional level intended to bring into the community investment projects both soft and hard in order to consolidate the partnership relations among the members of these structures. Taking into account the two financing programs, Galați County is part of a number of partnerships within the projects lodged for the period 2014-2020.

In the following, it is shown a situation of the projects proposed by the Cross-border Cooperation Association Lower Danube Euroregion, a structure whose member is also the county public administration:

\begin{tabular}{|c|c|c|c|}
\hline Priority & Project Budget & Name of the Project & $\begin{array}{l}\text { General Objective of } \\
\text { the Project }\end{array}$ \\
\hline $\begin{array}{l}1.2 \text { - Promotion and } \\
\text { support for research } \\
\text { and innovation }\end{array}$ & $\begin{array}{l}\text { Eur } 1,485,821.00 \text {, out } \\
\text { of which non- } \\
\text { reimbursable financing } \\
\text { is Eur } 1,299,456.4\end{array}$ & $\begin{array}{l}\text { CBC HealthNet - The } \\
\text { efficiency of obstetric- } \\
\text { gynecological and } \\
\text { pediatric medical } \\
\text { services in Galați and } \\
\text { Cahul }\end{array}$ & $\begin{array}{l}\text { Improvement of } \\
\text { obstetric, gynecological } \\
\text { and pediatric services } \\
\text { of the population in } \\
\text { Galați County, Cahul } \\
\text { County and Cantemir } \\
\text { County by enabling the } \\
\text { access of population to } \\
\text { quality services and the } \\
\text { establishment of a } \\
\text { public-private } \\
\text { partnership }\end{array}$ \\
\hline $\begin{array}{l}4.1 \text { - Support for the } \\
\text { development of health } \\
\text { services and access to } \\
\text { health }\end{array}$ & $\begin{array}{l}\text { Eur } 1,446,027.00 \text { out of } \\
\text { which non- } \\
\text { reimbursable financing } \\
\text { is Eur } 1,299,345.00\end{array}$ & $\begin{array}{l}\text { PROMemory } \\
\text { Development of } \\
\text { mental health } \\
\text { infrastructure in } \\
\text { Romania and the } \\
\text { Republic of Moldova }\end{array}$ & $\begin{array}{l}\text { Bettering the mental } \\
\text { health of the } \\
\text { population in two } \\
\text { counties in Romania } \\
\text { (Galați and Vaslui) and } \\
3 \text { counties in the } \\
\text { Republic of Moldova } \\
\text { (Chișinău, Cahul and } \\
\text { Cantemir) by } \\
\text { facilitating the access of } \\
\text { population to mental } \\
\text { health services of } \\
\text { quality and buiding-up } \\
\text { a public-private } \\
\text { partnership between } \\
\text { the } 2 \text { hospitals and } 2 \\
\text { NGOs working in the } \\
\text { field of providing } \\
\text { mental health services. }\end{array}$ \\
\hline $\begin{array}{l}2.1-\text { Promoting and } \\
\text { preserving cultural and } \\
\text { historical heritage }\end{array}$ & $\begin{array}{l}\text { Eur } 1,644,910.00 \text { out of } \\
\text { which non- } \\
\text { reimbursable financing } \\
\text { is Eur } 1,480,419.00\end{array}$ & $\begin{array}{l}\text { EtnicCULT } \\
\text { Promoting } \\
\text { ethnographic culture } \\
\text { and traditions in } \\
\text { Romania and the } \\
\text { Republic of Moldova }\end{array}$ & $\begin{array}{l}\text { The promotion of } \\
\text { cultural patrimony at } \\
\text { bilateral level between } \\
\text { Romania and the } \\
\text { Republic of Moldova } \\
\text { through the common } \\
\text { valorisation of }\end{array}$ \\
\hline
\end{tabular}




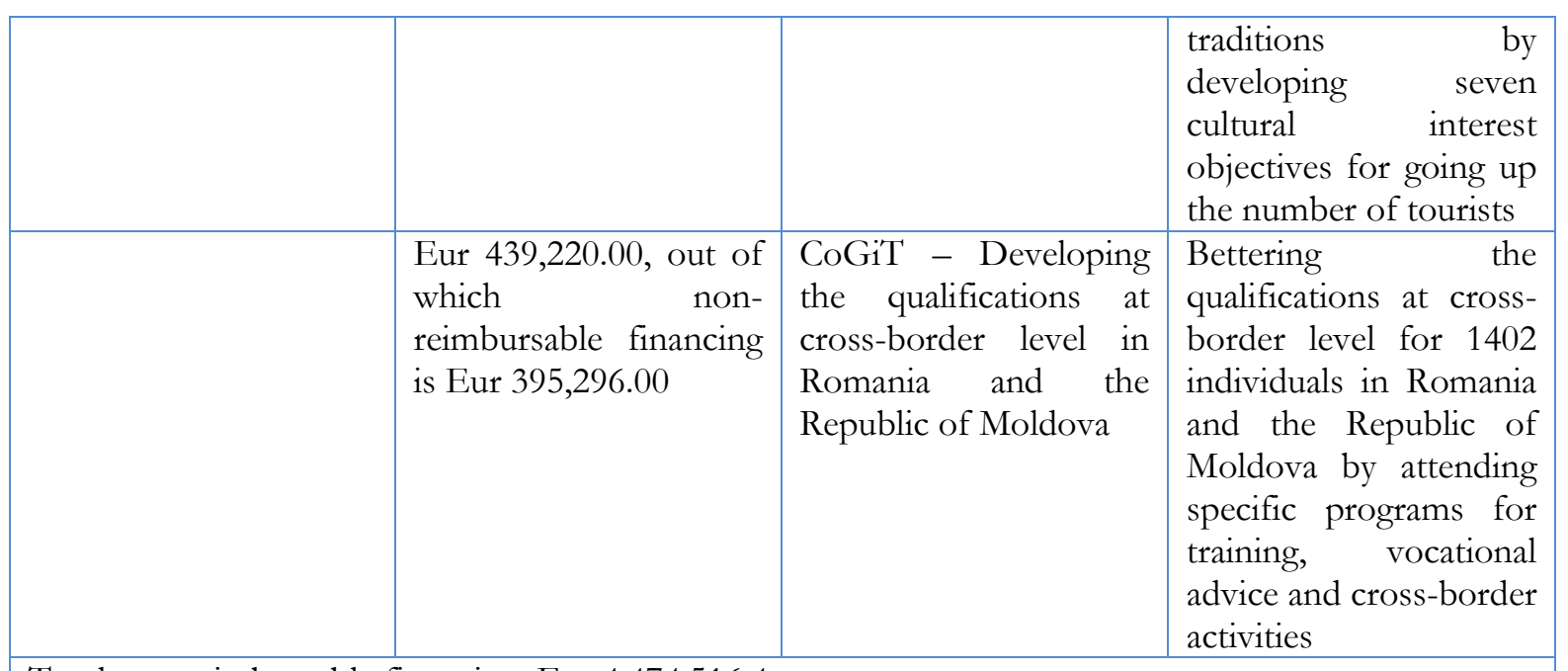

Total non-reimbursable financing: Eur 4,474,516.4

Joint Operational Program Romania-Republic of Moldova 2014-2020

Source: Personally processed data

(http://www.mdrap.ro/comunicare/presa/comunicate/241-de-proiecte-depuse-in-cadrul-programului-operationalcomun-romania-republica-moldova-2014-2020? fbclid=IwAR1ODvQsDDlZm7UWeInpa2Z67T1bJRnzduysLT6inF9ERSAF2tqvH4XS08)

Within the Joint Operational Program Romania-Republic of Moldova 2014-2020, there have been launched two calls for proposals, "soft" (projects not having an infrastructure component or the value of this component is less than one million euro) and "hard" (projects that have an infrastructure component of at least one million euro), which registered 241 applications for funding from the beneficiaries across the eligible area. Out of the total number of submitted projects, 162 target the funds allocated to the call for "soft" projects, and 79 projects request financing for "hard" investment.

\begin{tabular}{|c|c|c|c|}
\hline Priority & Project Budget & Name of the Project & $\begin{array}{l}\text { General Objective of } \\
\text { the Project }\end{array}$ \\
\hline $\begin{array}{l}4.3-\text { Preventing and } \\
\text { fighting organized crime } \\
\text { and police cooperation }\end{array}$ & $\begin{array}{l}1,485,821.00 \text { out of } \\
\text { which non-reimbursable } \\
\text { financing is Eur } \\
1,298,925.00\end{array}$ & $\begin{array}{l}\text { CBC-Safety - Preventing } \\
\text { and combating } \\
\text { organized crime and } \\
\text { police cooperation } \\
\text { through the cross- } \\
\text { border centers in the } \\
\text { Romania-Ukraine } \\
\text { border }\end{array}$ & $\begin{array}{l}\text { Bringing up the level of } \\
\text { trust of the citizens by } \\
3 \% \text { in RO and by } 8 \% \text { in } \\
\text { UA and the security by } \\
\text { improving the efficiency } \\
\text { of cooperation between } \\
3 \text { police service } \\
\text { structures in Romania } \\
\text { and Ukraine for } \\
\text { preventing and } \\
\text { combating cross-border } \\
\text { organized crime }\end{array}$ \\
\hline $\begin{array}{l}4.1 \text { - Support for the } \\
\text { development of health } \\
\text { services and access to } \\
\text { health }\end{array}$ & $\begin{array}{l}\text { Eur 1,485,821.00 out of } \\
\text { which non-reimbursable } \\
\text { financing is Eur } \\
1,257,669.00\end{array}$ & $\begin{array}{l}\text { MemoryHealth } \\
\text { Increasing the access of } \\
\text { the population in the } \\
\text { Odessa region and in } \\
\text { the Tulcea County to } \\
\text { mental health services }\end{array}$ & $\begin{array}{l}\text { Improving the mental } \\
\text { health of the population } \\
\text { in Tulcea County and in } \\
\text { Odessa region by } \\
\text { facilitating the access of } \\
\text { population to quality } \\
\text { mental health services } \\
\text { and setting up a public- } \\
\text { private partnership } \\
\text { between the } 2 \text { hospitals } \\
\text { and } 1 \text { NGO working in } \\
\text { the field of providing }\end{array}$ \\
\hline
\end{tabular}




\begin{tabular}{|c|c|c|c|}
\hline & & & mental health services \\
\hline $\begin{array}{l}2.1-\text { Promoting and } \\
\text { preserving cultural and } \\
\text { historical heritage }\end{array}$ & $\begin{array}{l}\text { Eur 1,110,655.00 out of } \\
\text { which non-reimbursable } \\
\text { financing is Eur } \\
999,589.50\end{array}$ & $\begin{array}{l}\text { Ethnic Cult- Craftsmen } \\
\text { Network - Promoting } \\
\text { local culture and } \\
\text { traditions through cross- } \\
\text { border craft activities in } \\
\text { Romania and Ukraine }\end{array}$ & $\begin{array}{l}\text { Promotion of the } \\
\text { cultural patrimony at } \\
\text { bilateral level through } \\
\text { the joint turning to } \\
\text { account of local crafts } \\
\text { and traditions and the } \\
\text { development of cultural } \\
\text { infrastructure in Tulcea } \\
\text { County and the Odessa } \\
\text { region }\end{array}$ \\
\hline \multicolumn{4}{|c|}{ Total non-reimbursable financing: $3,556,183.5$ euro } \\
\hline \multicolumn{4}{|c|}{ 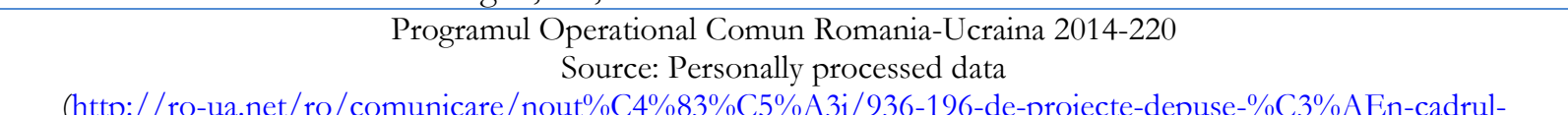 } \\
\hline
\end{tabular}

The calls for projects launched within the Joint Operational Program RomaniaUkraine 2014-2020 recorded 196 projects submitted by potential beneficiaries from the eligible border areas of the two partner states. Out of these, 35 projects have been lodged under the call for hard projects (projects with an infrastructure component of at least Eur 1 million), having a total requested non-reimbursable amount of over EUR 49 million, and the allocated amount being exceeded by over $150 \%$. The most accessed investment priority is 4.1 "Support for the development of health services and the facilitation of access to health services". The interest of potential beneficiaries for the SOFT project call (projects that do not have an infrastructure component or the value of this component is less than EUR 1 million) is equally high, with 161 submitted projects, with a total value requested by over $€ 57$ million, the amount allocated to SOFT projects being exceeded by over 230\%. Most of them target Priority 2.1 "Preservation and promotion of cultural and historical heritage".

The purpose of creating these Euroregions is the ability of a Euroregion to react in a local, national and European context (Sabău, 2006)

\section{Conclusions}

More than a third of the EU citizens are living and working in the border regions of Europe. These borders have both a direct and an indirect impact on their lives, as well as the projects implemented in these areas.

The projects have recorded countless actual achievements for the population in various areas, such as transport, education, energy, and health, the labor market through training or job creation.

Even though it has been invested considerably, there is a significant economic potential that has not been turned to advantage in the border areas due to the lack of confidence, the problems caused by various crises in the regions or the existence of negative attitudes among neighboring countries.

\section{References}

1. Herman, E. (2011a), The Impact Of The Industrial Sector On Romanian Employment, Journal of Knowledge Management, Economics and Information Technology, Volume I, Issue 6, October 2011.

2. Ilies, A., (2004) România. Euroregiuni, Editura Universitalii din Oradea, Oradea.

3. Prisecaru, P., (2004) Politici comune ale Uniunii Europene, Editura Economica, Bucureçti.

4. Săraru, C.-S.,(2011) „Considérations sur les accords de coopération transfrontalières entre les unites administratives-territoriales limitrophes des zones frontalières de la Roumanie et les structures similaires dans les pays voisins", in "Curentul Juridic" nr. 2(45)/2011, p. 88.

5. Sabăn C.,(2006) Euroregiunile - forme si structuri teritoriale de cooperare transfrontaliera, http:/ / steconomicenoradea.ro/ anale/volume/2006/ economie-si-administrarea-afacerilor/ 60.pdf. 
6. Brie M., Blaga D.,(2015) Identity rematch in the European space, in Cultural Diplomacy at the East and West Borders of the European Union.

\section{Webbibliography}

- http://mwn.mfa.gov.md/img/docs/Lista-Tratate-Bilaterale_16_09_15.pdf, accesat in data de 12.09.2015 - Lista tratatelor bilaterale incheiate de Republica Moldova, pp. 136-152

- http://mmw.ier.ro/sites/default/files/pdf/St\%202_Cooperarea\%20transfrontaliera_final.pdf

- http://legislatie.just.ro/Public/DetaliiDocument/53040

- bttps:// www.aebr.eu/en/members/map_of_members.php

- bttps:// mwn.cjsm.ro/download/CAPITOLUL\%208\%20\%20COOPERARE\%20TRANSFRONT ALIERA\%CC\%86_1.pdf)

- bttp://mmw.euroregiune.org/

- bttp:// www.actedj.ro/)

- bttp:// wnw.mdrap.ro/dezvoltare-regionala/4970/-7572/-9278

- http://mmw.fonduri-ue.ro/ro-md

- bttp:// wnw.fonduri-ue.ro/ ro-ua

- http://mmw.mdrap.ro/comunicare/presa/comunicate/241-de-proiecte-depuse-in-cadrul-programuluioperational-comun-romania-republica-moldova-2014-2020?fbclid=IwAR1ODvQsDDIZm7UWeInpa2Z67T1bJRnzduysLT6inF9ERS AF2tqvH4XSO8

- http:// ro-ua.net/ro/ comunicare/nout\%C4\%83\%C5\%A3i/936-196-de-proiecte-depuse-\%C3\%AEncadrul-programului-de-cooperare-rom\%C3\% A2nia-ucraina-2014-2020.btml

- http:// wmw.ier.ro/sites/default/files/pdf/St\%202_Cooperarea\%20transfrontaliera_final.pdf 